\title{
The Mechanisms of Cult Production *
}

\author{
Xavier Márquez Victoria University of Wellington
}

This chapter argues that leader personality cults are typically produced by a specific set of mechanisms of flattery inflation. It describes how loyalty signaling, emotional amplification, and direct production mechanisms can combine, under specific circumstances, to transform ordinary flattery into full-blown practices of ruler worship. And it argues for attending to the specific conditions that make possible the operation of these mechanisms, showing how patronage relationships in particular provide fertile ground for the emergence of personality cults. Moreover, the chapter argues that both ancient and modern leader cults depend on similar mechanisms, despite clear differences in context and function. I illustrate the operation of these mechanisms with many modern examples and an extended disussion of one ancient example, the abortive cult of Caligula during the Roman Principate.

Keywords: personality cults, Caligula, flattery inflation, Hugo Chávez, Mao Zedong, Stalin

\section{Introduction}

False, hypocritical praise has long been thought to be a problem for powerful rulers, as the testimony of political moralists and advisors to princes in both the East and the West indicates. ${ }^{1}$ Clearheaded rulers have long understood its dangers; ${ }^{2}$ a ruler who cannot see through the praises of sycophants is at risk of losing power, since flattery is not credible as a signal of their loyalty. ${ }^{3}$ Yet many ruler "courts", ${ }^{4}$ both ancient and modern, appear to be prone to flattery. Indeed, in some cases flattery of the ruler becomes so widespread and excessive that scholars speak of "cults of personality."

Consider just a few examples from several very different modern political regimes. In the 1980s, Romanian dictator Nicolae Ceauescu was routinely called "the Giant of the Carpathians", "the Source of Our Light", "the Treasure of Wisdom and Charisma", "the Great Architect", "the Celestial Body", and "the New Morning Star" by major public figures, and "court poets" wrote embarrassing encomiums to his rule (Sebestyen 2010, p. 161). In Zaire in 1975, Mobutu Sese Seko was hailed as a new "Prophet" and "Messiah", and his Interior Minister at the time even proposed replacing crucifixes in schools with Mobutu's image (Young and Turner 1985, p. 169). Beginning in the late 1930s, Francisco Franco's sycophants compared him to Julius Caesar, Charlemagne,

*I benefited from discussion at the 'Ruler Personality Cults' workshop at the Aarhaus Institute for Advanced Studies in June 2017. My thanks to the participants in this workshop for constructive and useful feedback.

${ }^{1}$ See, for example, Xenophon, Hiero, 1.15; Confucius, Analects 15.11; Machiavelli, The Prince, chapter 23 (entitled "How Flatterers Should Be Avoided").

${ }^{2}$ Mao Zedong told Ho Chi Minh in 1966 (when he was about to hit the peak of popular adoration during the cultural revolution): "I advise you, not all of your subjects are loyal to you. Perhaps most of them are loyal but maybe a small number only verbally wish you 'long live,' while in reality they wish you a premature death. When they shout 'long live,' you should beware and analyze [the situation]. The more they praise you, the less you can trust them. This is a very natural rule." (quoted in Leese 2011, p. 186).

${ }^{3} \mathrm{~A}$ formal treatment of why flattery is generally not credible as a signal of loyalty can be found in Wintrobe (2000), who calls it the 'dictator's dilemma'.

${ }^{4}$ Here I use the word "court" in an informal sense, as a clique of influential people who have regular and relatively unstructured access to a ruler. 
Napoleon, El Cid, Charles V, and most of the kings of the "Golden Age" of Spain; routinely praised him as a "military genius" and said to be "providentially ordained" as savior of Spain, a veritable "messiah of civic redemption;" called him "the Sun" and the "Father of Peace;" and exalted his intelligence, political acuteness, work habits, physical stamina, literary acumen, and even his sense of humor and his skills as a hunter, fisherman, and golf player (Fernández 1983, pp. 311-324). And in Syria in the 1990s, president Hafiz al-Assad was praised as the country's "premier pharmacist", as well as the country's premier teacher, doctor, and lawyer, among other things (Wedeen 1999, pp. 1, 12).

In many cases, such flattery does not remain confined to elite figures in the media or in the ruler's immediate court, but gives rise to widespread ritual practices of ruler worship, genuine "cults" of the leader that demand the participation of many different social groups to recognize the leader's exalted status. The cults of Lenin and Stalin in the Soviet Union, Mao in China, the Kim family in North Korea, Mussolini in Italy, and Hitler in Germany are the most well-known of these, ${ }^{5}$ but such phenomena can be found elsewhere as well, including in comparatively open political contexts like the Venezuela of Hugo Chávez. These forms of flattery seem sometimes humorous or bizarre. Yet they are puzzling, disproportionate to the achievements or charisma of their object: who could possibly believe that Hafiz al-Assad was indeed Syria's premier pharmacist, and what could possibly be the point of publicizing this ridiculous claim?

In this chapter I identify the mechanisms through which ruler flattery emerges, and the circumstances that transform it into mass rituals of adoration. ${ }^{6}$ In particular, I note the importance of interactions between mechanisms of loyalty signaling and mechanisms of emotional amplification for the emergence and development of what I call "flattery inflation". ${ }^{7}$ Moreover, I argue that the kind of semantic inflation visible in many leader cults is most likely under conditions of relatively unstructured competition for the favor of powerful patrons, and I suggest that the mechanisms identified by this theory better account for the emergence of excessive ruler flattery and mass personality cults than theories emphasizing purely cultural "mentalities" or the direct promotion of "charismatic" authority. I illustrate this account with ancient and modern examples of personality cults, emphasizing the continuities between these phenomena across the divide of modern media and communications.

The chapter is structured as follows. First, I define a leader cult in terms of its communicative dimensions (which include flattery), and identify the main mechanisms that can give rise to cults. In particular, I point to loyalty signaling, direct production, and emotional amplification as the three primary processes that can force the recognition of the ruler's status and charismatic authority from a large public. I then focus specifically on how loyalty signaling and ritual amplification can produce flattery inflation cascades, and illustrate these processes with a case study of the abortive cult of the Roman emperor Caligula in the context of the broader history of the cult of the Roman emperors, showing how these mechanisms have validity beyond the modern era.

\footnotetext{
${ }^{5}$ The cult of Stalin is the most systematically studied of these. For overviews of the Stalin cult's genesis and functions, see Tucker (1979); Plamper (2012); Ennker (2004). The key work on the Lenin cult is by Tumarkin (1983), and the Mao cult has been studied extensively by Leese (2011). The cult of Mussolini is one of the main foci of the study of FalascaZamponi (1997) on the aesthetics of power in fascist Italy; there are detailed studies of its genesis and content in Gundle, Duggan, and Pieri (2013). The literature on Hitler is unmanageably vast, but Kershaw (1987) is a good starting point for understanding the construction of his cult. The cults of the Kim family are less well studied due to the severe difficulties of access faced by researchers, but Tertitskiy (2015) and Myers (2010) offer some useful discussion, and the journalistic account of Demick (2009) is well worth consulting.

${ }^{6}$ For a discussion of the importance of mechanisms in social explanation, see Elster (2007).

${ }^{7}$ The phrase comes from Alois Winterling's revisionist biography of Caligula (Winterling 2011), p. 188.
} 


\section{Cult Artifacts, Cult Mechanisms, and Cult Functions}

A leader cult is a communicative phenomenon. When scholars speak of a leader cult, or a cult of personality, they point to widespread communicative activity that is understood by participants to express veneration or worship of the rulers. ${ }^{8}$ This activity is characterized by the concerted production of communicative artifacts (from monumental statues to verbal praise) that signal, express, or recognize the ruler's exceptional qualities or individual status, his "charisma" in Weber's sense of the term (Weber 1978, pp. 241-243).

Three points about this characterization of leader cults as communicative phenomena are worth elaborating. First, the communicative artifacts characteristic of a cult often, but not always, include representations of the leader: paintings and hagiographies, poems and movies, etc. But some cult artifacts at best symbolize a connection to the leader, rather than directly representing him. Early in the Cultural Revolution, for example, mangoes came to be treated as sacred artifacts because of their connection to Mao (Chau 2010; Dutton 2004); but the mangoes themselves did not strictly speaking represent Mao. These mangoes can be considered cult artifacts because in some communicative contexts, activities connected with them (bowing before replicas of the mangoes, placing them in special places, drinking the boiled juice of the mangoes, reproducing them in commercial products) signaled veneration or worship of Mao, and were understood as such by participants. The mangoes referred to Mao, but did not describe his exceptional qualities; activities connected with the mangoes did, however, express recognition of Mao's charisma.

Second, while individual praise of rulers is common in all political regimes, it is only in the case of cults that such activity is interpreted as worship or veneration. In politically significant cult phenomena, worship is also widespread and coordinated in some fashion, not just sporadic and localized. Widespread veneration or worship indicates the normative recognition of the ruler's exceptional qualities, his or her "charisma". It is because cult artifacts are widespread, and because they are interpretable as worship of the leader, that we can speak of the social (rather than merely individual) recognition of the leader's charisma.

Finally, despite the fact that cults involve the social recognition of a leader's charisma, this social recognition is not a description of the sincerity of individual participants in cult practices. Though cult communication, like all communication, can be sincere, it can also be hypocritical or deceptive. The key point for our purposes is that cult artifacts make recognition of the leader's charisma (his exalted status and exceptional qualities) normative, and thus transform it into authority. ${ }^{9}$ Insofar as people follow the social norm to worship or venerate the leader (i.e., to recognize the leader's exceptional qualities in a variety of practices) then the leader will have some charismatic authority, regardless of whether this recognition is sincere or not. And not following a public norm to recognize the charisma of the leader in turn leads to more or less severe consequences for the individual (depending on the context).

Generally speaking, cult communicative artifacts work as public signals of the social recognition of the charisma of the leader. They provide "common knowledge" that others recognize the charismatic authority of the leader both explicitly, insofar as cult artifacts visibly acknowledge and describe the leader's exceptional qualities; and implicitly, insofar as the material value

\footnotetext{
${ }^{8}$ The term "cult of personality" comes from the German Romantic notion of a Personenkultus, the exaltation of the individual personality (Plamper 2004, pp. 22-33). It was first used politically by Marxists (including Marx himself, who complained about what he saw as a "cult" emerging around him in 1877), and brought into much wider circulation by Khrushchev's condemnation of Stalin's personality cult in his "Secret Speech" to the 20th Party Congress. Given the polemical origins of the phrase "cult of personality", I prefer to use the more neutral terminology of "leader cult".

${ }^{9}$ As Weber notes, charismatic authority is dependent on the "free recognition" by the followers of the exceptional qualities of the leader (Weber 1978, p. 241). But this recognition must be public: there must be common knowledge that others recognize the leader's charisma.
} 
and the effort involved in the production of cult artifacts serve as costly public signals of this recognition. The social recognition of charisma is in turn intensified the more cult communicative artifacts pervade public spaces: if alternative characterizations of the leader are not visible (e.g., communicative artifacts that belittle the leader, or describe him or her in ordinary ways are prohibited or forcibly marginalized), the normative default appears to be the recognition of the leader's charismatic authority.

The communicative artifacts produced in a cult convey the ruler's exceptional qualities, charisma, or status in three different ways. First, they directly express some association between the leader and other ideas. Direct expression can be in the form of descriptions of the leader's personal qualities (for example, the epithets of Romanian dictator Nicolae Ceauescu mentioned above), or associations with more abstract concepts (e.g., in the 1930s Stalin was typically called the "Father of Peoples" and associated with the authoritative interpretation of Marxism-Leninism). We can speak here about the "express content" of cult artifacts: the particular ideas that are expressed (verbally or visually or in other media) in connection with the leader, and which provide meaningful content to his charisma. ${ }^{10}$

Second, cult artifacts can have material value that communicates status. The most obvious example of this is the material value of paper money printed with portraits of the leader (e.g., the portrait of Mao in Chinese Yuan notes), but it is also possible to speak of the material value of a statue, or of a gift to the leader (e.g., the gifts to the Kim family rulers in the International Friendship Exhibition museum in Pyongyang). ${ }^{11}$

Finally, cult artifacts can also recognize or express the leader's high status and exceptional qualities by displaying the impressive effort of their producers. A monumental statue; an extravagant display of praise; "stormy and prolonged applause"; these are all potential ways in which an otherwise ordinary communicative artifact might be used to recognize the leader's high status or exceptional qualities by credibly establishing that the producers of the artifact have devoted costly resources to honouring him. ${ }^{12}$

\section{The Mechanisms of Cult Production}

We can speak here, with Muller (2019), of the different kinds of "value" of cult artifacts for the recognition of a leader's charisma. This value can be derived from their semantic content ("semantic value"), their material composition ("material value"), and/or the costs to their producers ("signaling value"). The utility of particular kinds of cult artifacts for the recognition of the leader's charismatic authority will depend on a combination of these forms of value; but whether a particular artifact has one or another of these forms of value will depend in part on the mechanism through which it is produced.

In historical cases of leader cults, cult artifacts have been created through three distinct mechanisms. First, there is direct or centralized production, the intentional use of the bureaucratic authority of the state or other organizations to produce articles praising the leader, commemorative statues and paintings, hagiographic biographies, propaganda posters, etc. Direct production of cult artifacts standardizes the semantic value of cult artifacts, allowing for particular kinds of associations between the leader and other ideas while prohibiting others. Second, there is loyalty signaling, which motivates individuals to express praise of the leader and to publicly recognize his charisma in order to take advantage of opportunities for advancement or to avoid social sanction. Loyalty

\footnotetext{
${ }^{10}$ Muller (2019) speaks of the "ideological value" of cult artifacts in this connection.

${ }^{11}$ I take the idea of the "material value" of cult artifacts from Muller (2019).

${ }^{12}$ Muller (2019) speaks similarly of the "focal value" of cult artifacts, though does not emphasize the degree to which such value comes from personally costly display by the producers of the artifacts.
} 
signaling primarily determines the signaling value of cult artifacts, but it may also affect their material value insofar as the latter serves as a credible signal of support for the leader. Finally, there is ritual amplification, in which communicative cult artifacts are produced within a ritual context as part of a process of amplification of pre-existing emotional attachments to the leader. Ritual amplification affects all three forms of value.

These mechanisms do not necessarily work independently of each other in particular cases. The competition for power at the highest levels of a regime can lead to costly loyalty signaling by leading figures that in turn results in the redirection of the state's bureaucratic apparatus towards the production of cult artifacts and the promotion of rituals of worship that amplify emotion and lead individuals to produce more cult artifacts. For example, the cult of Stalin in the Soviet Union emerged partly as a result of the competition for power within the Politburo of the Communist Party, in which Lazar Kaganovich's attempts to consolidate his position against others in the inner circle by signaling his extreme loyalty to Stalin led to the use of state and party authority for the production of cult artifacts and rituals (e.g., the organization of Stalin's 50th birthday celebrations). This, in turn, prompted large-scale loyalty signaling among Soviet citizens and the ritual amplification of their attachments (Ennker 2004; Márquez 2018).

Similarly, the cult of Mao during the cultural revolution intensified as a result of competition at the highest levels of the Chinese Communist Party, where loyalty signaling by multiple figures (including Lin Biao and members of the Central Cultural Revolution Group) led to the redirection of resources towards the production of cult artifacts (e.g., millions of copies of the "Little Red Book") and the encouragement of groups (like the Red Guards) whose actions then induced millions to engage in loyalty signaling by participating in rituals of worship (Leese 2011; Márquez 2018).

Nevertheless, each of these mechanisms works via different processes and has different implications for the functions of leader cults. In what follows I explain each mechanism, provide examples, and note their different consequences for the politics of leader cults.

\section{Direct production}

Direct production is the simplest mechanism of cult production. We can understand direct production as the attempt to use the bureaucratic authority of organizations to increase the charismatic authority of the leader by directing state or party agencies to produce representations of the leader calculated to persuade audiences of the leader's charismatic qualities or his exalted status. Many leader cults, including the cults of the Kim family in North Korea and the cults of many of the leaders of Eastern European Communist parties, have been partly produced by the direct use of state power to create such representations. ${ }^{13}$ Writers' Unions, propaganda departments, and other organizations have been enlisted to create artwork, produce hagiographies, and prevent the production of unauthorized representations of the leader. Great care is taken by these organizations to ensure that leader representations and leader praise have a consistent ideological content.

The attempt by state institutions to produce or increase the charismatic authority of leaders is usually interpreted as a way of increasing their legitimacy, especially in times of crisis. For example, Stalin's cult is conventionally dated to his 50th birthday celebrations in December 1929 (Plamper 2004, p. 21), during the collectivization drive, when the legitimacy of the young Soviet regime would have been greatly endangered, while the Franco cult in the 1940s emerged under conditions of severe scarcity during and immediately after the Spanish Civil War (Payne 1987, p. 118).

\footnotetext{
${ }^{13}$ See, for the North Korean case, Tertitskiy (2015); the memoirs of Jang Jin-sung, a former member of a North Korean propaganda department, are also worth consulting (Jin-sung 2014). For a discussion of the organizations involved in cult production in several Eastern European cases, see Klimó (2004); Main (2004); and Mocanescu (2004).
} 
And it is plausible to think that 'states beset by economic failure and by social conflict invariably respond by seeking to strengthen symbolic legitimation' (Rees 2004, p. 4), though whether an increase in legitimation through cult-building accrues to the state, the regime, or the leader is not always clearly specified in scholarly work that emphasizes the legitimating functions of cults and the direct production of cult artifacts. ${ }^{14}$

Strictly speaking, the direct production of communicative cult artifacts can only make use of organizational rational-legal legitimacy (as found in the bureaucratic authority of well-functioning state or party agencies) to increase leader charismatic legitimacy. While it is possible that increases in the legitimacy of a leader achieved through the direct production of cult artifacts may redound to the legitimacy of state or party organizations, sometimes increases in leader legitimacy can come at the expense of the legitimacy of other organizations. Thus, for example, during the Cultural Revolution in China, increased adulation of Mao went hand in hand with attacks on the authority of the Party and many state institutions.

Because direct cult production activities may increase the legitimacy of the leader rather than that of the state or the ruling organization as such, they will tend to be associated with the consolidation of personal power within a regime (Svolik 2012, pp. 80-81), i.e., the process through which a ruler becomes progressively less constrained by other regime leaders. Thus, the emergence of the Stalin cult was not only associated with the collectivization crisis, but also with the consolidation of Stalin's personal power within the Politburo; and similarly the Franco cult was at its height while he was consolidating his power during and immediately after the civil war years. ${ }^{15}$

It is worth stressing that direct cult production can only work to legitimate the leader if the descriptions of the leader's qualities or exceptional status are credible to their intended audiences, and hence actually persuasive; incredible claims do not produce legitimation, even if they saturate public space or are repeated ad nauseam. ${ }^{16}$ To the extent that leaders are aware of the need for credibility, they will attempt to tamp down the more implausible claims made on their behalf, or to associate themselves with unverifiable or vague narratives of national pride. Thus Stalin's 'editorial' interventions in his own cult texts tended to soften the language used by his sycophants (Davies 2004); and North Korean cult propaganda tends to associate the leader with the unity of the nation (Myers 2010), though it also sometimes promotes incredible claims for signaling reasons.

In any case, although a state, particularly an authoritarian state, can usually flood public space with representations and praise of the leader, including artifacts that represent the leader in association with particular ideological content, the saturation of public space with these communicative artifacts, even if accompanied by punishments for the production of unsanctioned cult artifacts, need not result in the amplification of popular emotional attachment to leaders, or in the internalization of the ideological content of propaganda. As Paul Veyne once noted, much propaganda of this sort is "without viewers" (or at least without attentive viewers); ordinary people do not necessarily understand the nuances of the ideological messages being communicated, or even pay much attention to them (Veyne 1988). ${ }^{17}$

\footnotetext{
${ }^{14}$ Work that assumes cults legitimate leaders and/or regimes includes Rees (2004); Plamper (2004); Strong and Killingsworth (2011); and Cohen (2007). I have surveyed the many problems with scholarly uses of the concept of legitimacy in Márquez (2016b).

${ }^{15}$ On the dating of the consolidation of Stalin's personal power, see Khlevniuk (2005). On the dating of the consolidation of Franco's power, see Payne (1987), p. 126.

${ }^{16}$ On the importance of credibility to legitimation, see Márquez (2016b). Mercier (2017) surveys the extensive literature on gullibility and propaganda and finds that "incredible" propaganda is typically rejected by its intended audiences.

${ }^{17}$ Consider how little attention we pay to the images of political leaders in currency; they are part of the background of interaction, not meant to be studied closely, even if these pictures often also have some ideological content. Veyne
} 
Nevertheless, the permeation of public space with centrally produced cult artifacts can create normative expectations for the recognition of the leader's charisma. The very omnipresence of communicative cult artifacts produced by the state acts as a powerful signal that people are $e x$ pected to recognize the charisma of the leader in public settings. They make praise of the leader normative, and describe the language to be used when recognizing his charisma. As the historian Steven Kotkin has noted in the context of the 1930s in the Soviet Union, people reacted to all-encompassing Bolshevik propaganda by learning to "speak Bolshevik" (Kotkin 1995), namely using the cues of official discourse to navigate a difficult political environment. Mutatis mutandi the same is true of cult propaganda; as Lisa Wedeen documents in the case of Syria (1998), during Hafiz al-Assad's rule Syrians learned to use the language of the cult to avoid sanction and get ahead even when it was entirely impossible for authorities to verify their belief in it; and much other cult propaganda elsewhere is scrutinized in everyday life merely for clues to the right sort of language to use in "official" situations to avoid potential punishment. Omnipresent cult propaganda can thus lead to loyalty signaling.

\section{Loyalty Signaling}

Cult-building via loyalty signaling typically emerges when there is common knowledge that there are rewards or punishments arising from credibly and publicly recognizing (or failing to recognize) the leader's exceptional qualities. This expectation may be bureaucratically induced by the activities of state or party agents, ${ }^{18}$ or it may be generated by a small group that is particularly attached to the leader for independent reasons (e.g., the Red Guards during the early cultural revolution, Leese 2011). But once this expectation is in place, people will be incentivized to signal their loyalty to the leader; and the credibility of these signals will be directly related to the observable cost people incur when they produce communicative cult artifacts.

This cost need not be purely material. Voluntarily engaging in behaviours that incur in peer disapproval or loss of dignity can credibly indicate one's loyalty, as when people repeat obviously absurd flattery of the leader in public. Willingness to publicly say that Hafez al-Assad was Syria's "premier pharmacist" (Wedeen 1999, pp. 1, 12) or that Kim Jong-il had mastered teleportation to avoid being tracked by American satellites (Hassig and Oh 2009, p. 55) served as a credible signal of submission to these leaders (cf. Svolik 2012, pp. 80-81), since those uttering the praise were implicitly violating social norms against speaking nonsense to emphasize the unbridgeable status distance between themselves and these leaders. Even the violation of a norm against leader worship may serve to indicate the seriousness of a person's commitment to the leader, as those who violate the norm lose face among their peers. "Nauseating displays of loyalty" constitute costly signals of support for a leader precisely because they are frowned upon by others; and there is evidence that such costly signaling is partly responsible for cult-building behaviour in contemporary China (Shih 2008).

It is worth noting in this respect that the cult artifacts produced via loyalty signaling can be quite different in their semantic content than those produced by direct means. Direct cult production by the state will tend to produce cult artifacts calculated to persuade audiences of the charisma of the leader, and hence will emphasize otherwise believable representations, whereas credible loyalty signals may be effective precisely insofar as they express unbelievable views of the

notes that much monumental art glorifying ancient rulers was physically inaccessible to most people, and not meant to be studied closely.

${ }^{18}$ For example, state agents may police adherence to certain rituals of worship, as in North Korea during mourning rituals for Kim Il Sung and Kim Jong Il, when members of the Inmiban (neighbourhood committees) ensured that people participated in these rituals (Demick 2009, p. 101). 
leader. Sufficiently extravagant praise - flattery - is not persuasive to others (and hence cannot legitimate the leader), but it can be credible as a signal of commitment to the leader.

Moreover, in these circumstances the semantic content of such signals can be subject to a process of inflation that pushes them further and further away from believability. Because people have incentives to signal loyalty to gain rewards or avoid punishments, both people who are genuinely committed to the leader, and people who just want to gain the rewards of signaling loyalty (or avoid the punishments) will produce cult artifacts. ${ }^{19}$ In order to encourage distinctions between those genuinely committed and opportunists, leaders may thus encourage ever more elaborate displays of flattery - in essence increasing the "cost" people must pay to signal their loyalty - while the very scarcity of rewards may in any case incentivize individuals to produce such displays. The "signaling value" of any particular cult artifact - that is, its value as a means of gaining rewards or avoiding punishments - will thus be dependent on its scarcity: overproduction of particular cult artifacts "cheapens" them. Those wishing to present themselves as genuinely loyal must then spend more effort increasing the "signaling value" of their cult artifacts, which often involves the production of ever more extravagant or unbelievable flattery - at least until the costs of self-abasement or norm-breaking equal the symbolic and material benefits of being seen as a genuinely loyal supporter of the leader.

The early period of the Cultural Revolution in China is particularly abundant in examples of this inflationary dynamic. Highly committed Red Guards established an expectation that ordinary people needed to visibly show support for Mao (and recognize his extraordinary qualities) to avoid harassment or worse. This expectation in turn incentivized ordinary people to memorize quotations from the "Little Red Book", to participate in spontaneous displays of support for Mao, like "loyalty dances", or to wear Mao badges (Leese 2011). At the same time, Red Guards competed among themselves to show their radicalism and commitment to Mao, leading them to punish ever more minor infractions of the norm. The overall effect of this process was to ratchet upwards the effort required to be safe from harassment, and to devalue common signals of support over time. For example, when everyone wore Mao badges, wearing them became less credible as a signal that the person genuinely and sufficiently recognized Mao's charismatic authority. People wishing to "stand out" for their commitment to Mao (earning the rewards for this commitment, or avoiding the punishments for insufficient respect) thus started to wear more badges, or larger badges, or to wear these badges directly on their skin (Leese 2011, pp. 216-217).

A similar, if less dramatic, example of this inflationary dynamic can be found in contemporary China, where party efforts to promote the exalted status of Xi Jinping (Luqiu 2016), a form of "direct cult production", have induced some degree of grassroots signaling. For example, the Chinese government recently introduced a smartphone app called "Study the Great Nation," which provides access to Xi Jinping's latest speeches, quizzes on his latest pronouncements, and other study tools for "Xi Jinping Thought". The app has been apparently highly successful, with more than 100 million downloads. Yet though some people have clearly embraced it out of commitment to Xi Jinping, it is clear that the vast majority of people are using it because the party has ordered officials to promote the app and to penalize people who do not use it. According to reporting in the New York Times, "schools are shaming people with low app scores" and "Government offices are holding study sessions and forcing workers who fall behind to write reports criticizing themselves" (Hernández 2019), leading people to use the app more in order to avoid sanctions. ${ }^{20}$ At the same time, because the app "allows users to earn points", users can compete with each other to

\footnotetext{
${ }^{19}$ Economists call this a "pooling" rather than a "separating" equilibrium.

${ }^{20}$ These competitive dynamics have also created incentives for cheating, and accordingly an entire industry of cheating software (allowing people to earn "points" without engaging with the app) has also arisen (Hernández 2019).
} 
show their commitment to Xi Jinping and the party - points that may be useful in other material ways, such as promotions at work. Both the sanctions and rewards artificially increase the effort involved in using the app, lending high "scores" in the app "signaling value".

As these examples make clear, loyalty signaling differs from direct cult production also in that it is a decentralized process. People produce communicative cult artifacts because there are social norms that provide rewards for doing so (or punishments for not doing so), which may in turn lead to the development of markets in cult paraphernalia. Today, for example, there is a lively market in Putin cult objects (Cassiday and Johnson 2013), which the state does not tightly regulate, simply because there exist social rewards in some contexts from visibly displaying loyalty to Putin (and because some people participate in ritual contexts that amplify their attachments to Putin). One result of this is that cult artifacts produced through loyalty signaling are less standardized than those produced by the centralized processes described in the previous section; thus, for example, grassroots artifacts of the Lenin cult are immensely various, while the productions of the state tended to have a far narrower ideological content (Tumarkin 1983).

Nevertheless, because cult-building through loyalty signaling requires the existence of expectations of rewards or punishments for recognizing the charisma of the leader, much of it emerges in the context of patronage networks, where career advancement depends more on the credibility of client loyalty than on meeting explicit legal-rational criteria or achieving realistic objectives. This was often the case in Leninist parties, where cadres competed to offer ever more elaborate flattery to reassure their superiors of their loyalty in a treacherous ideological climate or to bid for resources allocated on the basis of indeterminate or particularistic criteria (Gill 1980; Gill 1984; Ennker 2004; Rolf 2004a).

At the extreme, the fear of losing one's career or one's life drove cult behaviour among party cadres. For example, during the Great Terror, fear of denunciation may have unreasonably increased the amount of applause given to Stalin's speeches, as cadres feared being denounced as insufficiently loyal. ${ }^{21}$ Other people who depended on state patronage, such as Soviet scientists, were also highly affected by the expectations of the Stalin cult. For example, when Stalin intervened in the dispute over Soviet linguistics in 1950, attacking the views of N. Ia. Marr on language and class (which had been dominant in the Soviet Union until that time), other linguists quickly disowned Marr, and immediately sent telegrams and letters to journals asking that their work (previously following Marr's line) be modified or retracted. ${ }^{22}$ Stalin's judgment even on fields remote from his ostensible expertise was evidently impossible to challenge publicly, as terrified scholars feared the loss of career opportunities or worse from being seen to oppose Stalin; he was "the coryphaeus of science".

But patronage relationships can generate cult-building incentives even where the consequences of non-compliance are less dire. Thus cult building through loyalty signaling appears to be common in what Juan Linz called "patrimonial" or "sultanistic" regimes (Chehabi and Linz 1998), where patronage relationships pervade the state (Márquez 2016a, chapter 4). We thus find cultbuilding behaviour in the Duvaliers' Haiti (Diederich and Burt 1973); Mobutu's Zaire (Young 1994, pp. 168-172); Nguema's Equatorial Guinea (Sundiata 1990, p. 129; Decalo 1985); Idi Amin Dada's Uganda and Bokassa's Central African Republic (Decalo 1985); Trujillo's Dominican Republic (Wiarda 1968, chapter 7); and Gaddafi's Libya (Pargeter 2012, chapter 4), all of which are commonly considered patrimonial regimes. While in some of these cases cults were sometimes pro-

\footnotetext{
${ }^{21}$ Solzhenitsyn dramatized this behaviour in a well-known anecdote (Solzhenitsyn 1973, pp. 69-70). While the anecdote may be fictionalized, it seems clear that such fears existed; Stalin himself expressed annoyance with the practice of "over-clapping" during his speeches (Davies 2004, pp. 35, 40).

${ }^{22} \mathrm{~A}$ full account of the linguistics affair can be found in Pollock (2005). For more on the panicked reactions of linguists to Stalin's intervention, see Zubkova (1998), p. 127.
} 
duced in more or less centralized ways - for example, Trujillo devoted bureaucratic resources to producing school textbooks extolling his rule - their most excessive manifestations typically came from people attempting to signal their loyalty (or attempting to prevent others from denouncing them for insufficient loyalty). In Trujillo's Dominican republic, for example, it became common knowledge that painters who created flattering representations of Trujillo were well-rewarded (Wiarda 1968, p. 133), while newspaper columnists who failed to mention his achievements were often the object of vilification through anonymous letters (sometimes written by Trujillo himself). In these circumstances, it is unsurprising that sycophants prospered, and cult content became highly exaggerated, with comparisons between Trujillo and God becoming quite common.

\section{Ritual amplification}

Loyalty signaling often occurs in ritual contexts, such as mass meetings where people are aware of other's reactions and wish to distinguish themselves as especially loyal to the ruler. But the production of cult artifacts can occur in ritual contexts for reasons other than loyalty signaling. In particular, successful rituals can produce what I call emotional amplification: the intensification of emotional attachments to the central symbols of the ritual, and the consequent production of communicative artifacts expressing such emotional commitments. ${ }^{23}$

Following Randall Collins, I shall call an "interaction ritual" any activity where people are co-present, jointly focused on some set of symbols, and aware of each other's attentional focus (Collins 2004; cf. also my more extended discussion in Márquez 2018). Much sociological research since Durkheim's pioneering studies (Durkheim 1995) indicates that ritual participation helps amplify emotional commitments to particular sets of symbols that are the focus of the ritual and to the group through processes of physical synchronization (Xygalatas et al. 2011; Lang et al. 2015). This definition of ritual is capacious enough to encompass the wide variety of participatory practices found in leader cults, from large scale mass meetings (the Nuremberg rallies, the eight "Mass Receptions" of the Red Guards, electoral rallies in Chavez' Venezuela) to regular rituals in workplaces or other contexts, to informal and ad-hoc practices (like "loyalty dances" in China). Participation in rituals of worship may be encouraged by the state, or by elites in a regime, or it may be induced by the need to signal support for, and recognition of the charisma of, the leader; but once people come to participate their attachment to the leader and their sense of belonging to a particular community united around the leader may be amplified, at least if the ritual is successful. ${ }^{24}$

The production of cult artifacts in ritual contexts is especially important in low-coercion environments. While the state can use its authority to coerce participation in rituals of worship, and there can be strong social pressures to signal support by means of ritual participation (as, for example, in the Cultural Revolution, when many people feared that lack of participation in "loyalty dances" and "quotation gymnastics" would lead to harassment or worse - see Leese 2011), in less coercive contexts where neither the state nor social pressures provide especially strong incentives to produce cult artifacts the main producers of cult artifacts will tend to be participants in interaction rituals centered on the leader.

For example, the cult of Hugo Chávez in Venezuela seems to have emerged mostly through

\footnotetext{
${ }^{23}$ Rituals not only amplify emotion, but also articulate meanings, and in particular articulate meanings that give shape to a community and place it in a larger context, as many theorists of ritual have noted (Rappaport 1999). I focus here on the capacity of ritual for emotional amplification, noting only that this is an important way in which feelings of belonging to a community are strengthened.

${ }^{24}$ Unsuccessful rituals may produce boredom and a sense of alienation, leading to detachment from the central symbols of the ritual.
} 
processes of ritual amplification rather than costly signaling and direct production, though both costly signaling and direct production played an important role in the later intensification of the cult (Márquez 2018). During Chávez's years in power his constant electoral campaigns (there were 13 major elections in his 14 years in power) provided plenty of opportunities for interaction rituals focused on his person, and Chávez was a skilled practitioner of these ritual forms, able to draw on pre-existing symbols of communal identity and "genealogical" narratives connecting the present to the revolutionary past of Venezuela to generate intense experiences of belonging (Michelutti 2017). People who already had some reason to like Chávez gravitated not only towards these electoral rituals, but to a variety of other popular organizations (e.g., the "Círculos Bolivarianos" and later on the "Unidades de Batalla Electoral", both composed of small groups dedicated to the Bolivarian project and to Chávez personally) whose activities allowed for the emergence of Chávez-focused interaction rituals where emotional attachments to his person were renewed and amplified (Hawkins and Hansen 2006; López Maya and Lander 2011). ${ }^{25}$

As a result, by the end of his time in power, a sizable minority of the population was intensely attached to Chávez, to the point where on his death spontaneous, intense mourning was widespread, the mausoleum where Chávez is interred became a site of pilgrimage (with government encouragement), and several public Chávez shrines appeared in popular sectors in Caracas (Ultimas Noticias 2013). The point here is not that there was no encouragement by the government to the production of cult artifacts; if nothing else the fact that by the end of Chávez' time in power the government controlled the airwaves allowed it to produce cult artifacts very effectively. Moreover, struggles for power at the top of the ruling party hierarchy also intensified signaling dynamics among Venezuelan leaders, leading to inflationary pressures on the production of cult artifacts (Márquez 2018). But many other cult artifacts (Chávez-themed mural painting in poorer areas, the creation of Chávez chapels, visits to the Chávez mausoleum, tweets saying "I am Chávez") were more spontaneously produced by people whose voluntary participation in rituals with Chávez at their center renewed and amplified their emotional commitments to him, and who did not have a pressing need to signal support to gain resources or avoid punishments.

Another example of the role of ritual amplification in producing cult artifacts can be found in the cult of Maurice Thorez, the leader of the PCF during and immediately after World War II (Morgan 2016). The cult of Thorez among members of the French Communist Party (PCF) cannot be explained by the state's use of coercive authority, or by an expectation that members needed to credibly signal support of Thorez, simply because the party was not in power and the most severe sanction it could use against people who did not participate in cult activities was exclusion. The cult grew mostly because the PCF was what Anne Kriegel has called an "oppositional microsociety" (cited in Morgan 2016, p. 8), and cult rituals provided an opportunity for party members to affirm their belonging together in a hostile climate.

\section{Flattery Inflation and the Cult of Caligula}

The mechanisms of cult production discussed above are not dependent on particular features of modern society or culture. They have also produced cult-building behaviours in temporally and culturally distant contexts. In what follows, I illustrate the operation of these mechanisms with a more extended discussion of the (failed) cult of Caligula in the early Roman empire, set in the context of the broader history of the Roman imperial cult.

\footnotetext{
${ }^{25}$ Small group "study circles" (like some of the Chavista organizations mentioned above) have often played a role in promoting leader cults; group study rituals of Mao's "Little Red Book", for example, played a role in promoting his cult within the PLA (Leese 2011, pp. 97-102).
} 
The Roman imperial cult was a "literal" cult, in the sense that the deified emperor became the object of a formal ritual practice, supported by state resources. Such cults were rare for living people; most emperors were only formally deified in the Roman core of the empire after death, though living emperors were often the object of cultic practices in the Greek-speaking provinces (Hammond and Price 2003, p. 1338). For our purposes in this chapter, however, we will focus on the broader set of "cult-building" practices in the Imperial period, including the production of extravagant flattery and the awarding of extraordinary honours. These were practices that exalted the status of the emperor far above the status of other members of the elite, without necessarily creating literal cult rituals. In any case, the distinction between sacred and secular honours was less marked for Roman culture than our own: as Gradel puts it, "divine cult was an honour, differing in degree but not in kind from 'secular' honours" (Gradel 2002, p. 3), and as such only one of many honours that helped increase the status of the emperor and made the recognition of his charisma normative.

Roman society in the late Republic was not, by modern standards, an egalitarian society, though Republican ideas provided a counterweight to its more inegalitarian tendencies. In particular, the senatorial elite had a strong sense of its political significance, and members considered themselves each other's equals. Senators jockeyed over relative status in the many rituals of Roman life (marked by such things as the seating order in the circus or the theatre, the order of voting in the senate, the lavishness of their hospitality in their private parties, elections to political office, the number of their clients, etc.) but they remained notional social equals. Struggles for power from the time of the Gracchi onwards weakened these intra-elite egalitarian norms, since by the end of the Republican period, very powerful and wealthy individuals controlled enough resources to induce loyalty signaling by other members of the elite, including the granting of divine honours to living individuals. For example, though the evidence is somewhat controversial, it appears that Julius Caesar was granted divine honours by the Senate during his lifetime (Hammond and Price 2003, p. 1338).

The end of the civil wars, and the rise of Augustus, changed the balance of power between senators and powerful military leaders decisively in favor of the imperator. But although from Augustus (Caligula's great grandfather, the first emperor) onward, the imperator was the most powerful person in Rome, he continued to depend on the senatorial aristocracy to rule the empire. The senate constituted the group from which the emperor drew the people who could command the legions, coordinate the taxation of the provinces, and in general govern the empire and keep him in power. It was also the group that constituted the greatest threat to his position, since segments of the senatorial aristocracy could also conspire against him and potentially overthrow him, selecting a different emperor, especially since principles of hereditary succession were not clearly institutionalized.

The cooperation of the senate, in turn, depended in part on maintaining the fiction that senators remained the emperor's equals. It is significant in this respect that Augustus was known as the princeps, literally the "first citizen" (hence the early Roman Empire is normally called the "principate"). During his time, the standard republican offices were filled more or less normally and retained their meaning as markers of status (though elections were often rigged, when they were held at all, to produce the results decided in advance by the emperor); the senate voted triumphs and special festivals in honour of particular people and events, including voting divine honours to the dead emperor (Price 1987), and confirmed the emperor's own position. Even the title imperator originally meant nothing more than military commander, though it came to be applied exclusively to the princeps or certain members of his family (Momigliano and Cornell 2003). Most importantly for our purposes, the first two emperors (and many later ones as well) did not compel the sorts of marks of obeisance typical of earlier Hellenistic monarchies, where the "status 
distance" between the rulers and the members of the traditional elite had been much larger than in Rome: proskynesis (prostration), kissing the feet or the robe, worship as a god, elaborate forms of address, clear hereditary succession, etc.

Augustus in particular went out of his way not to signal any sort of intention to become a "king," that is, a ruler like the Hellenistic monarchs (Winterling 2011, pp. 9-11), despite the fact that the Roman polity had become a "monarchy" in all but name, something that was common knowledge among all members of the elite. He lived in a relatively small house on the Palatine hill; stood for office in the normal way, and sometimes resigned it; and let the senate conduct the business of the republic in appearance, cleverly signaling his intentions so that senators could reach the "right" result (i.e., the result Augustus wanted). The reason for this cautious behavior is that signaling an intention to become a king (that is, to widen the status distance between himself and the senatorial aristocracy) increased the ability of disgruntled senators to conspire against him. This was, after all, what happened to Julius Caesar (Augustus' adoptive father). By behaving in ways that signaled an intention to become a king in the Hellenistic sense (a rex), he threatened to destroy the foundations of senatorial status in the Republic. Rex was a status symbol that could still mobilize passions against those who tried to claim this status.

Yet the strong norm against the appropriation of kingship symbols by powerful individuals was not enough to prevent the emergence of the cult of Caligula a few decades after Augustus' death. The problem was that the social status of the emperor was not fully commensurate with the resources he controlled. Senators as a group preferred this situation of status equality. But individual senators could benefit (both materially and in status terms) from credibly signaling special loyalty to the emperor, who was of course "patron in chief," and controlled status and material resources that only he could allocate to the senators.

Such signaling could take two forms. First, senators could inform on each other. Yet excessive denunciations also increased the risk of actual conspiracies (as senators anticipating that they might be denounced could attempt to take power) and devastated the elite on which the emperor relied, so early emperors often attempted to curb excessive conspiracy-mongering (Winterling 2011, pp. 26-28, on Tiberius). But senators could also directly flatter the emperor, attempting to show how much they valued his person by costly acts that increased his status relative to theirs. The problem was that any particular form of flattery quickly became devalued, and the emperor lost the ability to distinguish genuine supporters from non-supporters. Moreover, flattery inflation tended to diminish the collective social status of the senatorial aristocracy: the more the emperor was praised, the more the senators were abased.

For example, in Roman elite society the morning salutatio was an important indicator of status: friends and clients visited their friends and patrons in the mornings, and the more visitors a senator had, the higher his status. But nobody could afford not to visit the emperor every morning, or to signal that they were not really "friends" with the emperor, since every member of the senatorial aristocracy was in a sense the emperor's client. So the morning salutatio at the emperor's residence turned into a crush of hundreds of senators, all of them jostling to gain the emperor's attention (Winterling 2011, p. 23). And while in principle, the senate retained some discretion in allocating honours to the emperor (triumphs, titles, etc.), individual senators could always sponsor extraordinarily sycophantic resolutions in the hopes of gaining something from the emperor (offices, marriages, etc.), and other senators could not afford not to vote for such resolutions due to the risk of potential denunciation by other senators.

In sum, flattery inflation was, from the point of view of the senators, a tragedy of the commons: as each senator tried to further his relative social status within the aristocracy, they tended to devalue their collective status. It was not necessarily a good thing from the point of view of the emperors either, who could not easily distinguish sycophantic liars and schemers from genuine 
supporters, and who often disliked the flattery (Winterling 2011, pp. 26-28, on Tiberius). So the emperors tried to dampen it or manage it to their advantage. Three potential responses to this problem can be distinguished.

First, emperors could try "ostentatious humility". As noted earlier Augustus lived in a relatively ordinary house by aristocratic standards, and refused to publicly usurp the Senate's business. This strategy attempted to tamp down inflationary pressures by providing a more or less credible fiction of equality between emperor and senators. But the fiction could work only if it did not come into conflict with the emperor's power. Senators needed to do what the emperor wanted, but the emperor could not explicitly order them to do so without undermining this fiction. This required a great deal of political skill and clever indirection, so less able political operators than Augustus (such as Tiberius, Augustus' immediate successor) were less successful at maintaining this fiction.

Tiberius instead tried a strategy of withdrawal, moving to Capri to avoid contacts with the senatorial aristocracy (Winterling 2011, p. 26), and complemented this strategy by explicitly banning the senate from granting him certain honours. Yet by banning the more public forms of flattery and removing himself from Rome, he inadvertently incentivized ambitious senators to denounce each other as a means of advancement. The more denunciations, moreover, the less actual conspirators had to lose, leading to a poisoned and dangerous atmosphere, especially as factions of Tiberius' family schemed over the succession. Most potential heirs did not live long; Caligula was the last man standing.

Caligula first tried the Augustan policy of indirection and ostentatious humility, and was reasonably good at it. But for reasons that are not entirely clear (though Winterling suggests they were related to attempts on his life - see Winterling 2011, p. 64), he seems to have changed tack in the third year of his reign to deliberately encourage flattery. He did this, in part, by taking the senators literally: when they said that he was like a god, he demanded proof of this, thus forcing them to worship him as a god and humiliating the particular senator. Or when he was invited to dinner, he forced senators to ruin themselves to please him. And he demonstrated contempt for their status by the way he behaved in the circus and elsewhere. (The famous story of how he named his horse a consul can be understood as one such insult). Yet the senators could not retaliate by revealing their true feelings; their coordination costs had increased and their individual incentives were always to flatter Caligula.

Strategically speaking, the point of this seems to have been to lessen his dependence on the senatorial aristocracy and to move the regime towards a Hellenistic model. For example, there is some suggestive evidence that Caligula might have been planning to move to Alexandria, an obviously symbolic move to the historic capital of the Hellenistic dynasts (Winterling 2011, pp. 9798). Encouraging runaway flattery inflation made conspiracies harder to pull off (since even the most innocuous comment could be used to betray the other conspirators) but also succeeded in completely humiliating the flatterers (in this case the senatorial aristocracy) and lowering their collective social status vis à vis the ruler. At the endpoint of this process (represented here by the status hierarchy of the Hellenistic dynasts), ambiguous language is no longer necessary to manage the relationship between the patron and his clients; their competitive self-abasement has widened their status distance so much that direct orders are no longer out of the question.

This was a high-risk strategy: deliberate humiliation, by striking at the core of the symbols of senatorial identity, also made some senators more willing to run the risk of conspiracy; even as these risks increased, the costs to their identity of allowing Caligula to humiliate them so directly also increased. In fact, according to Winterling, the humiliation of the aristocracy not only led to the downfall of Caligula, but also contributed to his characterization by later (aristocratic) writers as the "mad emperor" (Winterling 2011, pp. 187-191): Caligula symbols had become objects of 
hatred, since they never had a ritual context that charged them with positive emotional energy.

In sum, the cult of Caligula in Rome emerged through a process of loyalty signaling, and died when he was killed in $41 \mathrm{AD}$. But the processes of loyalty signaling that incentivized flattery inflation in his time did not stop then. The disparity in power between emperor and senators led to a gradual increase in the status distance between senators and emperor, to the point that by the time of Diocletian (284-305 AD) elaborate ceremonies of veneration were common among the aristocracy (Winterling 2011, p. 192). Even though Claudius, Caligula's immediate successor, tried again the Augustan strategy of ostentatious humility, the elite's incentives for both flattery and conspiracy that made Caligula's choices comprehensible remained in place and led to a further erosion of the senatorial aristocracy's status (Winterling 2011, pp. 192-193).

In any case, the broader emergence of cults of (living) emperors outside of the Roman elite (including cults to Caligula himself) cannot be fully explained by the same incentives to produce flattery that the senatorial elite faced. Instead, we need to turn to the ritual context of such cults (Price 1984, chapter 1). As noted above, cult rituals articulate meanings and amplify emotion. The cults of the Roman emperors in the many Greek-speaking cities of the empire, like the earlier cults of the Hellenistic kings, were responses to the unaccountable power of these new rulers, whose place in the community (at once outside of it, yet not rejected as alien and hostile) could at best be articulated in the familiar terms of divinity, and expressed in cult rituals (Price 1984, chapters 1 and 2). The emergence of such cults, however, also responded to the incentives inherent in the fact that the emperor controlled enormous economic resources. Cities in Asia minor could offer cult to the emperor as an expression of gratitude for benefits received, and to help secure further benefits from a power that could not be easily influenced in other ways (Price 1984, p. 66). While this strategy did not always work (cult offers were not always approved, and benefits were not always forthcoming, especially if the particular city did not follow through on completing a temple or endowing a priesthood), it was one means to compete for the patronage of the Imperial household, implicating the emperor in a "gift economy." 26

The benefits - in prestige and sometimes material resources - gained from being allowed (by the Senate or the emperor) to offer cult to the emperor were considerable enough that there is even evidence of competition among cities to do so, at least in Asia Minor (Price 1984, p. 64). It is also significant that, with few exceptions (mainly the cult of Augustus), cults to individual emperors tended to disappear with the death of the emperor (Price 1984, pp. 61-62); there was little point in maintaining a cult to an emperor who could no longer provide resources to a city. And within a particular city, wealthy people could offer to endow an imperial priesthood as a way to gain prestige within the community (Price 1984, pp. 63-64); the imperial cult, after all, involved the production of festivals and other rituals that must have enhanced many people's ordinary lives. To be sure, some of the later cult rituals appear to have been rather pro-forma, and we know very little about their reception by participants. But at least some festivals would have meaningfully integrated the emperors into the community's self understanding, and exploited emotional amplification to "routinize" the charisma of the emperor (Price 1984, pp. 58-59) - that is, make recognition of his charisma normative for everyone.

The normative recognition of an individual emperor's charisma diminished over time; there is a trend in the sources towards generic cults of the autokrator, the generic emperor (Price 1984, p. 58). It is a safe bet, too, that the emotional power of such rituals also diminished over time; the sources suggest that only the cult of Augustus had a genuine basis in Augustus' own charismatic authority, which was in turn rooted in his success pacifying the empire. But loyalty signaling

\footnotetext{
${ }^{26}$ For a similar process, see Rolf (2004b) on how Soviet institutions used renaming proposals to extract resources from the centre.
} 
by Roman and provincial elites kept the cults going, though ritual amplification must also have helped, especially in the early period; little "direct production" seems to have been needed, with few exceptions (including, interestingly, Caligula's cult - Price 1984, p. 68).

The specific form of the emperor cult in the Greek-speaking provinces of the empire - divine honours to a living emperor, administered by a priest and involving sacrifices at regular calendar dates - disappeared when its meaning came into conflict with emerging but central selfunderstandings of Greek and Roman culture. The coming of Christianity thus first undermined and then finally ended the explicit ritual aspect of the cult of the emperors (Price 1987). But the disappearance of cults granting explicit divine status to emperors did not, of course, mean the disappearance of rituals exalting the status of rulers. It only meant that the interaction rituals where this status was recognized changed, articulating the meaning of royal or imperial status in different symbolic terms. Loyalty signaling, direct production, and ritual amplification remained important mechanisms that increased or decreased the status of the ruler relative to the elite, and made recognition of his charisma more or less normative.

\section{Conclusion: Patterns of Cult Production}

As we have seen, leader cults can be produced by different mechanisms, though all these mechanisms are evident in different times and places, and are not tied to specific cultural formations. The specific meaning of the cult will, of course, be dependent on the cultural materials available (e.g., divine honours in Greek and Roman antiquity or association with the authoritative interpretation of Marxism-Leninism in the Soviet Union), but the mechanisms that mobilize these cultural materials, transforming honours into flattery and flattery into cult rituals, are of a more general kind. The primary mechanisms at work in any particular cult cannot be determined a priori: whether a leader cult emerges primarily because of direct production, loyalty signaling, or ritual amplification is a matter for empirical investigation. Nevertheless, some general patterns can be discerned within the historical evidence discussed above.

First, high material inequality tends to induce loyalty signaling, especially in patronage relationships that are poorly institutionalized. If the stakes are high enough, loyalty signaling at the elite level (flattery) can turn into mass direct production of cult artifacts, which in turn can induce ritual participation beyond the elite. Second, ritual amplification as a mechanism of cult production tends to be most important in situations where coercion is limited, and punishment for non-participation in cult rituals is rare. In such circumstances, only people with pre-existing commitments to a leader are likely to participate in cult rituals, and these rituals will become especially important to them if participants have other reasons to feel part of a distinct group in opposition to the rest of society. Finally, the direct production of cult artifacts is most likely when there is a conscious attempt to increase the legitimacy of a leader during crises, and whenever leaders succeed in consolidating power.

The particular effects and function of a leader cult depend on whether it is produced primarily via direct production, loyalty signaling, or ritual amplification. For example, while direct production corresponds to attempts to consciously boost the legitimacy of a leader, in the absence of mass loyalty signaling its effects are unlikely to be large. And while flattery inflation through loyalty signaling may force the widespread recognition of a leader's charisma, its long-term effects are unlikely to be large in the absence of non-coercive ritual contexts where these loyalties can be constantly renewed. More generally, whether a cult serves as a durable means for increasing the legitimacy of a leader or a state will depend in part on how the cult is produced. 


\section{References}

Cassiday, Julie A. and Emily D. Johnson (2013). "A personality Cult for the Postmodern Age". In: Putin as Celebrity and Cultural Icon. Ed. by Helena Goscilo. Abingdon: Routledge. Chap. 2, pp. 37-64.

Chau, Adam Yuet (2010). "Mao's Travelling Mangoes: Food as Relic in Revolutionary China". In: Past \& Present 206.suppl 5, pp. 256-275. DOI: 10.1093/pastj/gtq020.

Chehabi, Houchang E. and Juan J. Linz (1998). "A Theory of Sultanism 1: A Type of Nondemocratic Rule". In: Sultanistic regimes. Ed. by Houchang E. Chehabi and Juan J. Linz. Baltimore: JHU Press. Chap. 1, pp. 3-25.

Cohen, Yves (2007). "The Cult of Number One in an Age of Leaders". In: Kritika: Explorations in Russian and Eurasian History 8.3, pp. 597-634. DOI: 10.1353/kri.2007.0032.

Collins, Randall (2004). Interaction Ritual Chains. Princeton, N.J.: Princeton University Press.

Davies, Sarah (2004). "Stalin and the Making of the Leader Cult in the 1930s". In: The Leader Cult in Communist Dictatorship: Stalin and the Eastern Bloc. Ed. by Balázs Apor et al. London: Palgrave Macmillan, pp. 29-46.

Decalo, Samuel (1985). "African Personal Dictatorships". In: The Journal of Modern African Studies 23.2, pp. 209-237.

Demick, Barbara (2009). Nothing to Envy: Ordinary Lives in North Korea. New York: Spiegel \& Grau.

Diederich, Bernard and Al Burt (1973). Papa Doc: Haiti and its dictator. London: Penguin.

Durkheim, Emile (1995). The Elementary Forms of the Religious Life. Trans. by Karen E. Field. New York: Free Press.

Dutton, Michael (2004). "Mango Mao: Infections of the Sacred". In: Public Culture 16.2, pp. 161187.

Elster, Jon (2007). Explaining social behavior: more nuts and bolts for the social sciences. Cambridge and New York: Cambridge University Press.

Ennker, Benno (2004). "'Struggling for Stalin's Soul': The Leader Cult and the Balance of Social Power in Stalin's Inner Circle". In: Personality Cults in Stalinism - Personenkulte im Stalinismus. Ed. by Klaus Heller and Jan Plamper. Göttingen: V \& R unipress. Chap. 5, pp. 161-195.

Falasca-Zamponi, Simonetta (1997). Fascist spectacle: The aesthetics of power in Mussolini's Italy. Berkeley: University of California Press.

Fernández, Carlos (1983). El general Franco. 2nd ed., revised. Barcelona: Argos Vergara, p. 339.

Gill, Graeme (1980). "The Soviet Leader Cult: Reflections on the Structure of Leadership in the Soviet Union". In: British Journal of Political Science 10.2, pp. 167-186. DOI: 10.1017/S0007123400002088.

- (1984). "Personality cult, political culture and party structure". In: Studies in Comparative Communism 17.2, pp. 111-121. DOI: http:/ / dx.doi.org/10.1016/0039-3592(84)90008-5.

Gradel, Ittai (2002). Emperor Worship and Roman Religion. Oxford: Oxford University Press.

Gundle, Stephen, Christopher Duggan, and Giuliana Pieri (2013). The cult of the Duce: Mussolini and the Italians. Manchester: Manchester University Press.

Hammond, Mason and Simon R. F. Price (2003). "Ruler-Cult". In: The Oxford Classical Dictionary. Ed. by Simon Hornblower and Anthony Spawforth. Oxford: Oxford Univeristy Press, pp. 1338-1339.

Hassig, Ralph and Kongdan Oh (2009). The Hidden People of North Korea: Everyday Life in the Hermit Kingdom. Lanham: Rowman \& Littlefield Publishers.

Hawkins, Kirk Andrew and David R. Hansen (2006). "Dependent Civil Society: The Circulos Bolivarianos in Venezuela". In: Latin American Research Review 41.1, pp. 102-132. DOI: 10.1353/lar. 2006.0008 . 
Hernández, Javier C. (Apr. 7, 2019). "The Hottest App in China Teaches Citizens About Their Leader - and, Yes, There's a Test". In: The New York Times. URL: https: / / www.nytimes.com / 2019 / 04 / 07 / world / asia / china-xi-jinping-study-the-great-nation-app.html (visited on 04/12/2019).

Jin-sung, Jang (2014). Dear Leader. Trans. by Shirley Lee. London: Rider Books.

Kershaw, Ian (1987). The "Hitler Myth": Image and Reality in the Third Reich. Oxford and New York: Clarendon Press.

Khlevniuk, Oleg V. (2005). "Stalin as Dictator: The Personalisation of Power". In: Stalin: A New History. Ed. by Sarah Davies and James R. Harris. Cambridge: Cambridge University Press. Chap. 6, pp. 108-121.

Klimó, Árpád (2004). “A Very Modest Man: Béla Illés, or How to Make a Career Through the Leader Cult". In: The Leader Cult in Communist Dictatorships: Stalin and the Eastern Bloc. Ed. by Balázs Apor et al. Houndmills: Palgrave Macmillan, pp. 47-62.

Kotkin, Stephen (1995). Magnetic Mountain: Stalinism as a Civilization. Berkeley: University of California Press.

Lang, Martin et al. (2015). "Lost in the Rhythm: Effects of Rhythm on Subsequent Interpersonal Coordination". In: Cognitive Science 40.7, pp. 1797-1815. DOI: 10.1111/cogs.12302.

Leese, Daniel (2011). Mao Cult: Rhetoric and Ritual in China's Cultural Revolution. Cambridge: Cambridge University Press.

López Maya, Margarita and Luis E. Lander (2011). "Participatory Democracy in Venezuela: Origins, Ideas, and Implementation". In: Venezuela's Bolivarian Democracy: Participation, Politics, and Culture under Chávez. Ed. by David Smilde and Daniel Hellinger. Durham: Duke University Press. Chap. 2, pp. 58-79.

Luqiu, Luwei Rose (2016). "The Reappearance of the Cult of Personality in China". In: East Asia 33.4, pp. 289-307. DOI: 10.1007/s12140-016-9262-x.

Main, Izabella (2004). "President of Poland or Stalins Most Faithful Pupil? The Cult of Bolesaw Bierut in Stalinist Poland". In: The Leader Cult in Communist Dictatorships: Stalin and the Eastern Bloc. Ed. by Balázs Apor et al. Houndmills: Palgrave Macmillan, pp. 179-193.

Márquez, Xavier (2016a). Non-Democratic Politics: Authoritarianism, Dictatorship, and Democratization. London: Palgrave Macmillan.

- (2016b). "The Irrelevance of Legitimacy". In: Political Studies 64.1, suppl. DOI: 10.1111/14679248.12202.

- (2018). "Two Models of Political Leader Cults: Propaganda and Ritual”. In: Politics, Religion E Ideology 19.3, pp. 265-284. DOI: 10.1080/21567689.2018.1510392.

Mercier, Hugo (2017). “How gullible are we? A review of the evidence from psychology and social science". In: Review of General Psychology 21.2, pp. 103-122. DOI: 10.1037/gpr0000111.

Michelutti, Lucia (2017). ""We Are All Chávez" :Charisma as an Embodied Experience". In: Latin American Perspectives 44.1, pp. 232-250. DOI: 10.1177/0094582x16666023.

Mocanescu, Alice (2004). "Surviving 1956: Gheorghe Gheorghiu-Dej and the Cult of Personality in Romania". In: The Leader Cult in Communist Dictatorships: Stalin and the Eastern Bloc. Ed. by Balázs Apor et al. Houndmills: Palgrave Macmillan, pp. 246-260.

Momigliano, Arnaldo and Tim J. Cornell (2003). "Imperator". In: The Oxford Classical Dictionary. Ed. by Simon Hornblower and Anthony Spawforth. Oxford: Oxford Univeristy Press, p. 750.

Morgan, Kevin (2016). International Communism and the Cult of the Individual: Leaders, Tribunes and Martyrs under Lenin and Stalin. London: Springer.

Muller, Ruehl (2019). "Identifying the Cult of Personality Phenomena and the Visual Mechanisms that Explain Them: The Value Progression Model". In: Working paper. 
Myers, B. R. (2010). The Cleanest Race: How North Koreans See Themselves and Why It Matters. Melville House.

Pargeter, Alison (2012). Libya: The Rise and Fall of Qaddafi. New Haven: Yale University Press, p. 304. Payne, Stanley G. (1987). The Franco Regime, 1936-1975. Madison: University of Wisconsin Press.

Plamper, Jan (2004). "Introduction: Modern Personality Cults". In: Personality Cults in Stalinism Personenkulte im Stalinismus. Ed. by Klaus Heller and Jan Plamper. Göttingen: V \& R unipress, pp. 13-42.

- (2012). The Stalin Cult: a Study in the Alchemy of Power. Stanford and New Haven: Hoover Institution and Yale University Press.

Pollock, Ethan (2005). "Stalin as the coryphaeus of science: ideology and knowledge in the postwar years". In: Stalin: A New History. Ed. by Sarah Davies and James R. Harris. Cambridge: Cambridge University Press. Chap. 14, pp. 271-287.

Price, Simon R. F. (1984). Rituals and Power. Cambridge: Cambridge University Press.

- (1987). "From noble funerals to divine cult: the consecration of Roman Emperors". In: Rituals of Royalty: Power and Ceremonial in Traditional Societies. Ed. by David Cannadine and Simon R. F. Price. Cambridge: Cambridge University Press.

Rappaport, Roy A. (1999). Ritual and Religion in the Making of Humanity. Cambridge: Cambridge University Press.

Rees, E. A. (2004). "Leader Cults: Varieties, Preconditions and Functions". In: The Leader Cult in Communist Dictatorships: Stalin and the Eastern Bloc. Ed. by Balázs Apor et al. Houndmills: Palgrave Macmillan, pp. 3-26.

Rolf, Malte (2004a). “The Leader's Many Bodies: Leader Cults and Mass Festivals in Voronezh, Novosibirsk, and Kemerovo in the 1930s". In: Personality Cults in Stalinism - Personenkulte im Stalinismus. Ed. by Klaus Heller and Jan Plamper. Göttingen: V \& R unipress. Chap. 6, pp. 197206.

- (2004b). "Working Towards the Centre: Leader Cults and Spatial Politics in Pre-war Stalinism". In: The Leader Cult in Communist Dictatorships: Stalin and the Eastern Bloc. Ed. by Balázs Apor et al. Houndmills: Palgrave Macmillan, pp. 141-158.

Sebestyen, Victor (2010). Revolution 1989: The Fall of the Soviet Empire. New York: Knopf Doubleday.

Shih, Victor Chung Hon (2008). "'Nauseating' Displays of Loyalty: Monitoring the Factional Bargain through Ideological Campaigns in China". In: The Journal of Politics 70.4, pp. 1177-1192. DOI: $10.1017 /$ S0022381608081139.

Solzhenitsyn, Aleksandr (1973). The Gulag Archipielago, 1918-1956. Trans. by Thomas P. Whitney. Vol. I-II. New York: Harper \& Row.

Strong, Carol and Matt Killingsworth (2011). "Stalin the Charismatic Leader?: Explaining the Cult of Personality as a Legitimation Technique". In: Politics, Religion E Ideology 12.4, pp. 391-411. DOI: $10.1080 / 21567689.2011 .624410$.

Sundiata, Ibrahim K. (1990). Equatorial Guinea: colonialism, state terror, and the search for stability. Boulder, Colorado: Westview Press.

Svolik, Milan (2012). The Politics of Authoritarian Rule. Cambridge and New York: Cambridge University Press.

Tertitskiy, Fyodor (2015). "The Ascension of the Ordinary Man: How the Personality Cult of Kim Il-Sung was Constructed (1945-1974)". In: Acta Koreana 18.1, pp. 209-231.

Tucker, Robert C. (1979). "The Rise of Stalin's Personality Cult". In: The American Historical Review 84.2, pp. 347-366.

Tumarkin, Nina (1983). Lenin lives! The Lenin cult in Soviet Russia. Cambridge: Harvard University Press. 
Ultimas Noticias (29 March 2013). FOTOS: Inauguran capilla "Santo Hugo Chávez" en el 23 de enero. Newspaper Article. URL: http: / / www.ultimasnoticias.com.ve / Noticias / Actualidad / Politica/FOTOS-Inauguran-capilla-Santo-Hugo-Chavez-en-el-23.aspx.

Veyne, Paul (1988). "Conduct Without Belief and Works of Art Without Viewers". In: Diogenes 36.143, pp. 1-22.

Weber, Max (1978). Economy and Society. Berkeley: University of California Press.

Wedeen, Lisa (1998). "Acting "as if": Symbolic Politics and Social Control in Syria". In: Comparative Studies in Society and History 40.3, pp. 503-523. DOI: 10.1017/s0010417598001388.

- (1999). Ambiguities of Domination: Politics, Rhetoric, and Symbols in Contemporary Syria. University Of Chicago Press.

Wiarda, Howard J. (1968). Dictatorship and development: the methods of control in Trujillo's Dominican Republic. Gainesville: University of Florida Press.

Winterling, Aloys (2011). Caligula: a Biography. Berkeley: University of California Press.

Wintrobe, Ronald (2000). The Political Economy of Dictatorship. Cambridge and New York: Cambridge University Press.

Xygalatas, Dimitris et al. (2011). "Quantifying collective effervescence: Heart-rate dynamics at a fire-walking ritual". In: Communicative E Integrative Biology 4.6, pp. 735-738.

Young, Crawford (1994). "Zaïre: the Shattered Illusion of the Integral State". In: The Journal of Modern African Studies 32.02, pp. 247-263.

Young, Crawford and Thomas Turner (1985). The Rise and Decline of the Zairian state. Maddison: University of Wisconsin Pres.

Zubkova, Elena (1998). Russia After the War: Hopes, Illusions and Disappointments, 1945-1957. New York: ME Sharpe. 